\title{
Evli Bireylerde Manevi İyi Oluş, Ailede Yılmazlık ve Yaşamın Anlamı Arasındaki Yordayıcı İlişkiler ${ }^{1}$
}

\author{
Şüheda ÇALIŞKAN ${ }^{2}$ ve Bülent DİLMAÇ
}

\section{Öz}

$\mathrm{Bu}$ araştırmanın amacı, evli bireylerde manevi iyi oluş, ailede ylmazlık ve yaşamın anlamı arasındaki yordayıcı ilişkilerin incelenmesidir. Değişkenler arasındaki ilişkilerin belirlenmesi için AMOS 19 programı ile yapısal eşitlik modeli analizi yapıllmıştır. Çalışma grubunu 2018-2019 eğitim öğretim yllında Ankara'da bulunan bir devlet okulunda çocukları eğitim gören evli veliler ve okulda görev yapan evli öğretmenlerden gönüllü olan 324 kişi oluşturmuştur. Toplanan verilerin bir kısmı boş bırakma, soruları anlamama, eksik veri vb. sebeplerden elenmiş ve kalan 280 veri ile araştırmaya devam edilmiştir. Araştırmada katılımcıların demografik bilgilerini belirlemek için Kişisel Bilgi Formu, Spiritüel İyi Oluş Ölçeği, Yaşam Anlamı Ölçeği ve Aile Yılmazlık Ölçeği kullanılmıştır. Araştırmadan elde edilen bulgulara göre; ailede y1lmazlığı etkileyen bağımsız değişkenin $(t=5.91, p<0.01)$ manevi iyi oluş olduğu belirlenmiştir. Yaşamın anlamı değişkenine etki eden değişkenin $(\mathrm{t}=3.63, \mathrm{p}<0.01)$ ise manevi iyi oluş olduğu tespit edilmiştir. Ailede ylmazlık değişkenini etkileyen değişkenin $(\mathrm{t}=3.08, \mathrm{p}<0.01)$ yaşamın anlamı değiş̧keni olduğu belirlenmiştir.

Anabtar Kelimeler: Evli bireyler, Manevi iyi oluş, Ailede yılmazlık, Yaşamın anlamı

Relationships between Spiritual Well-Being, Resilience in the Family and the Meaning of Life in Married Individuals

\begin{abstract}
This research aims to examine the predictive relationships between spiritual well-being, resilience in the family, and the meaning of life on married individuals. The relationships between variables were analyzed using the AMOS 19 program for the structural equation model. The study group consists of 324 volunteers, including married parents whose children were educated at a public school in Ankara, and married teachers working at the school in the 20182019 academic years. Some of the collected data for reasons such as leaving blank, not understanding the questions, and missing data were omitted, and the research continued with 280 data. Personal Information Form and Spiritual Well-being Scale were used in order to learn the demographic information of the participants in the study, and the Meaning of Life Scale and Family Resilience Scale were also included. In the light of the findings obtained from the research; It was observed that the independent variable $(t=5.91, \mathrm{p}<0.01)$ affecting resilience in the family was spiritual well-being, and the variable affecting the meaning of life variable $(t=3.63, p<0.01)$ was spiritual well-being. It was also stated that the variable that affected the resilience variable in the family $(t=3.08, p<0.01)$ is the variable of the meaning of life.
\end{abstract}

Key Words: Spiritual well-being, Resilience in the family, Meaning in life

\section{Atıf İçin / Please Cite As:}

Çalışkan, Ş. ve Dilmaç, B. (2022). Evli bireylerde manevi iyi oluş, ailede yılmazlık ve yaşamın anlamı arasındaki yordayıc ilişskiler. Manas Sosyal Araştırmalar Dergisi, 11(1), 113-127.

Geliş Tarihi / Received Date: 2.04.2021

Kabul Tarihi / Accepted Date: 8.07.2021

\footnotetext{
${ }^{1}$ Bu çalışma Şüheda Çalışkan'ın Evli Bireylerde Manevi İyi Oluş, Ailede Yılmazlık ve Yaşamın Anlamı Arasındaki Yordayıcı İlişkiler” Yüksek Lisans Tezinden üretilmiştir

2 Psikolojik Danışman - Ankara Milli Eğitim Müdürlüğü, suheda.erd@gmail.com

iD ORCID: 0000-0001-5128-8778

3 Prof. Dr. - Necmettin Erbakan Üniversitesi Ahmet Keleşoğlu Eğitim Fakültesi, bulentdilmac@gmail.com

(D) ORCID: 0000-0001-5753-9355
} 


\section{Giriş}

Aile kurumu gerek toplum gerekse birey açısından oldukça önemlidir. Aile, yerini hiçbir sosyal grup ya da kurumun alamayacağı evrensel bir kurumdur (Kuşut, 2013, s. 1). Bireylere sosyalleşme konusunda ilk imkânı sunan bu kurum aynı zamanda toplumun şekillendiricisi ve yapıtaşıdır. Mutlu, müreffeh ve güçlü bir toplum, sağlıklı bireylerin oluşturduğu ailelerden oluşan bir toplumdur. Bu sağlıklı yap1 ise evlilik kurumu ile sağlanabilir. Evlilik kurumu toplumları ayakta tutan en önemli kurumlardan biridir (Süataç, 2010, s. 1). Evlilik; aile biçimleri, düşünce sistemleri bakımından birbiri arasında farklılıklar bulunan iki yabancı kişinin kendilerine ait yeni davranışlar ve yeni düşünce sistemleri ile oluşturduğu bir kurumdur (Turanli, 2010, s. 4).

Evlilik ile bireyler çeşitli ihtiyaçlarını karşılama, nesillerini devam ettirme, daha düzenli bir hayat yaşama gibi imkânlara sahip olurlar. Böylece bireylerin toplumsal işlevlerini yerine getirmeleri ve topluma uyum sağlamaları da kolaylaşır. Sağlıklı bir evlilik insan için bir mutluluk sığınağı görevini görür. Kişi evinde günün bütün zorluklarından arınabilir, duygu paylaşımını yaşayabilir. Ayrıca sağlıklı evlilik içinde olan bir birey için ev, kendini güvende ve ait hissettiği yerdir. Evliliğinde güveni hisseden kişilerin daha mutlu oldukları ve daha uzun ömürlü oldukları belirlenmiştir (Tarhan, 2014, s. 15-21).

İkinci Dünya Savaşı sonrası psikoloji ve psikiyatri bilimi ciddi şekilde ilerleme göstermiş, araştırmalar ise daha çok psikopatoloji odaklı olmuştur. İnsanların olumlu ve güçlü özelliklerini, potansiyellerini incelemek ve bunlarla ilgili araştırmalar yapmak büyük oranda ihmal edilmiştir. 1950'lere geldiğimizde insancil psikolojinin öncülerinden olan Rogers, Fromm ve Maslow psikolojinin ibresini psikopatolojiden çevirmiş, böylece yüzyıllardır felsefi olarak ele alınan mutluluk, ümitvar olma, insanın var oluşundan gelen olumlu özellikler, yılmazlık gibi kavramlar psikoloji araştırmalarının konusu olmaya başlamıştır. 1998 yılına geldiğimizde Amerikan Psikoloji Derneği'nin başkanlığını yapmakta olan Martin Seligman insancıl yaklaşımın temelini attığı bu yaklaşımı "Pozitif Psikoloji" olarak psikoloji dünyasına sunmuştur (Doğan, 2016). Pozitif psikoloji, psikoloji biliminin "normal" insanın nasıl daha iyi ve daha mutlu yaşayabileceğini araştırmasının gerekliliğine vurgu yapar. Pozitif psikolojide amaç, sadece negatife dikkat çekmek değildir. Pozitifi ortaya çıkarmak, desteklemek, insanlarda bu pozitif özelliklerin kalıcilığını sağlamaya çalısmak hatta toplumu bu pozitif özelliklerle yeniden inşa etmek pozitif psikolojinin hedeflerindendir. Bu bağlamda bireylerin güçlü yönlerine odaklanır ve bireylerin potansiyelini en yüksek seviyede kullanması gerektiğine vurgu yapar (Seligman ve Csikszentmihalyi, 2000, s. 5-14). Güçlü yönlere yapılan bu vurgu arttıkça yaşamda anlam, yılmazlık, iyi oluş, kişisel gelişim, travma sonrası büyüme gibi kavramlar psikoloji literatürüne girmeye başlamıştır.

Pozitif psikolojinin gelişmesi ile adeta yıldızı parlayan hayatın anlamı konusu psikolojide oldukça önem verilen ve üzerine de pek çok araştırmanın yapıldığı bir konu haline gelmiştir. Öyle ki Paul Wong, hayatın anlamı konusunun pozitif psikolojinin en önemli bileşeni olduğunu ve iyi oluşla ilgili tüm ölçeklerde mutlaka hayatın anlamı ile ilgili bir madde bulunması gerektiğini belirtmiştir. Frankl'a göre (2009, s. 113) yaşamda anlam kişinin yaşamını değerli kılan amaçlara sahip olması ile yakından ilgili olan, kişiden kişiye değişen ve yaşamın devam edebilmesi için temel olan güdüleyici bir etmendir. Anlamın özel yapısı, yalnızca bireyin kendisinin anlamı bulabilmesini gerektirir. İnsanın en kötü şartlarda bile yaşamını sürdürmesindeki en etkili faktör, yaşamında bir anlam olduğu bilgisidir. Nietzsche bu durumu şöyle ifade etmiştir: 'Yaşamak için herhangi bir 'neden' i olan kişi hemen her 'nasıl'a katlanabilir." Auschwitz toplama kampında yaşadıklarını anlatan Frankl, kamptaki tüm o güç şartlara rağmen mahkûmların hayatta kalabilmelerini bedensel olarak güçlü olmalarına değil, yaşamak için bir nedenlerinin olmasına bağlamıştır. $\mathrm{Bu}$ da anlamın ne kadar önemli ve evrensel bir insan motivasyonu olduğunu göstermektedir.

Anlamsızlık, bireyler kendilerini yönsüz, hedefsiz, çözümsüz, yetersiz olarak düşündüklerinde ortaya çıkar (Harlow ve Newcomb, 1990, s. 387-405) ve anlam yokluğu durumunda sıkınt1, depresyon, intihar düşüncesi gibi durumlar gözlemlenebilir (Akın ve Taş, 2011, s. 30; Arda, 2011, s. 9). Bunlar göz önüne alındığında anlamın hayatı yaşanılır kıldığı ve davranışlarımıza bir yön verdiği görülecektir. İnsanın anlam arayışına yönelik yapılan ilk klinik çalışmalar Frankl'’n logoterapisine dayanır.

Hayatta anlam arayışı insanlık tarihi kadar eskidir. İnsan "şey" lere anlam verebilen, düşünebilen yegâne canlı olarak diğer canlılardan ayrılmaktadır. Albert Camus (1998, s. 21): "Gerçekten önemli olan tek bir sorun vardır; intihar. Yaşam, yaşamaya değer mi değmez mi?’ sorusuyla bu anlam arayışına dikkat çekmiştir. Bizler anlam arayışımızı var oluşumuzun bir gerekliliği olarak sürekli yanımızda taşııı. Anlamsız olduğu düşünülen bir hayatı sürdürmek oldukça zorlayıcı iken, yaşamda anlam bulmak hayatı daha güzel 
daha yaşanılır kılar. Maalesef günümüz insanının da en büyük sorunlarından biri herhangi bir işle uğraşmadığında yahut kendisiyle ilgilenmediğinde yani boş kaldığında yaşamış olduğu "anlamsızlık" hissidir (Corey, 2008, s. 160).

Das'a (1998, s. 199) göre, anlamlar hayatımızda pek çok düzenleme yapar ve yeni durumların oluşmasına hizmet eder, insana yaşamak için nedenler sağlar. Böylece eylemlerimizi yönlendirmiş oluruz. Bu durum da yaşamdaki olaylar için kontrol işlevi görür. Anlamın varlığı, öz-değerin oluşmasına da katkı sağlar. Kısaca yaşamda anlam bulduğumuzda pek çok problem kendiliğinden çözülür ve hayatımız kıymetli bir hale gelir. Battista ve Almond (1973, s. 409-427) yaşamını anlamlı bulan kişilerin aynı zamanda yaşamlarını doyurucu bulduğunu belirlemiştir. Adler insanın ruhsal yaşamının bir anlamla belirlendiğini söyler.

Anlam arayışı, bireyi yeni firsatlar ve uğraşlar bulması için teşvik edebilmeli, bireyin yaşamsal tecrübelerini anlama ve anlamlandırma isteğini artırabilmeli ve bireyin yaşamının doğal bir parçası olmalıdır (Steger, Kashdan, Sullivan ve Lorentz, 2008, s. 199-228). Yani anlam bireyi harekete geçirebilmelidir. Bir bireyin anlam arayışı başarılı olduğunda bu durum o bireyi mutlu etmenin yanında ona karşılaşabileceği acılarla başa çıkabilecek bir güç ve beceri verir, bireyde güçlü bir irade meydana getirir. Yaşamda anlam bulmanın sağlıklı olmaya ve iyi hissetmeye de önemli bir katkısı olduğu düşünülmektedir (Ryff ve Singer, 1998, s. 1-28).

Pozitif psikolojinin önemli bir diğer konusu ise yllmazlık kavramıdır. Kavramın literatüre girişi bireysel çalışmalarla olmuştur ve başlangıçta bireyler için kullanılmıştır. Sürecin akabinde yılmazlı̆̆ın yalnızca bireyler için değil topluluklar ya da kurumlar için de geçerli olabileceği düşüncesi, yeni araştırmalara yer açmıştır (Gordon ve Song, 1994, s. 27-43). Aile yılmazlığı çalışmaları da bu düşüncenin etkisiyle başlayan topluluk bazlı yılmazlık araştırmalarındandır. Kaner ve Bayraklı ülkemizde aile yılmazlı̆̆ı konulu araştırmaların başlamasında öncü olmuşlardır (Bayraklı, 2010, s. 12; Bayraklı ve Kaner 2010, s. 48).

Yılmazlık Walsh (2006, s. 261-281) tarafindan bir zorluk ile karşılaşıldığında bu durumdan daha güçlü bir şekilde çıkmayı, bir kriz durumunda gelişim göstermeyi ve dayanıklı olmayı sağlayan aktif bir süreç olarak tanımlanmaktadır. Masten (1994, s. 3-25) ise yüksek risk grubundaki bireylerin; akademik başarısızlık, düşük özgüven, sosyal beceri eksikliği gibi olumsuz yönde olması muhtemel sonuçlar yerine başarılı sonuçlar elde etmelerini, karşılaştıkları güç durumlarla başa çıkabilmelerini ve yeni duruma adapte olmalarını, yaşadıkları travmatik bir deneyim karşısında hızla toparlanmalarını ifade eden bir kavram olarak yılmazlığı tanımlar. Literatürde ortak bir yılmazlık tanımı yoktur. Doğan da yılmaz bireyler için tekrar tekrar ayağa kalkabilen "hacıyatmaz" benzetmesi yapmaktadır (Doğan, 2016).

Yılmazlık, bir kişilik özelliğinden daha çok bir süreci kapsamaktadır (Luthar, Cicchetti ve Becker, 2000, s. 543-562). Kişilik gelişiminin genetik ve çevresel faktörlerin bileşiminden oluşması gibi, yılmazlık için de genetik bazı kolaylaştırıcı faktörler olsa da sonradan da geliştirilebilir bir özellik olduğu ifade edilebilir. Kişi yılmaz davranışlar göstermeyi öğrenebilir (Ekşi, Boyalı ve Ümmet, 2018, s. 1698).

Nasıl kimi bireyler zorluklar karşısında pes ederken kimi bireyler güçlenerek yoluna devam eder ve yılmazlık özelliği gösterirse, aynı şekilde kimi aileler sıkıntı ve zorluklar karşısında daha dirayetli ve güçlü kalırken, kimi aileler tam tersi bir durum sergileyip parçalanabilmektedir (Kaner ve Bayraklı, 2010, s. 48). Güçlükler karşısında yılmayan ve daha da güçlenerek yola devam eden bu ailelere yılmaz aileler denmektedir. Patterson'a göre (2002, s. 349-360) aile yılmazlı̆̆1, önemli aksakliklara veya zorluklara maruz kaldıktan sonra ailenin bu zor durumlara uyum sağlayabilmesi ve işlevlerini yerine getirmeye devam edebilmesidir. Yani aile yılmazlığı, fonksiyonel bir sistem olan ailenin stresli yaşam koşulları ve zorluklarından kurtulmayı başarması ve daha da güçlenmesi olarak ifade edilebilir. Bu krizler ve yaşam zorlukları tüm aile bireylerini etkiler, dolayısıyla ailenin işlevselliğini bozabilir. Yılmaz aileler krizi çözmeye ve aile bireylerinin özellikle de çocukların bu krizden olabildiğince az zarar görmesini sağlamaya, ortak kararlar almaya ve çatışmaları çözmeye çalışır (Walsh, 2002, s. 1-14).

Pozitif psikolojiye ait başka bir kavram olan "iyi oluş" kavramı içinde manevi iyi oluşu da barındırmaktadır. Bireyin fiziki, sosyal, psikolojik, duygusal, entelektüel ve manevi boyutlar yönünden tutarlı ve dengeli olması hali iyi oluş olarak adlandırılmaktadır (Adams, Bezner ve Steinhardt, 1997, s. 208218). Manevi iyi oluş ise Opatz (1986, s. 60-67) tarafindan insanın var oluşundaki anlam ve amaçları aramaya istekli olması, her şeyi sorgulaması, rahatlıkla açıklanıp anlaşılamayacak soyut şeyleri idrak etmesi şeklinde tanımlanmıştır. 
Maneviyat/spiritüellik kavramı din kavramıyla çok karıştırılan bir kavram olmakla birlikte aynı anlama gelmemektedir. Maneviyat dinin pratiklerine anlam katmaktayken, din maneviyatı derinleştirir (Adams vd., 2000, s. 166; Ingersoll, 1994, s. 105) Maneviyat dinin bir bileşeni olsa da sadece dini inanç ile sınırlandırılamayacak derecede geniş kapsamlıdır. Maneviyat sadece dindar kişileri kapsayan bir durum değildir, dini inancı olmayan kişiler de manevi değerlere sahip olabilir (Kızılırmak, 2015, s. 41). DSM-IV'e manevi ve dini yöndeki problemlerin eklenmesi ve psikomanevi uygulamalara olan ilginin artmastyla önemi iyice artan maneviyatın, sağlıklı bir ruh hali ve ruhsal gelişim için de oldukça önemli olduğu belirtilmektedir (Kasapoğlu, 2017, s. 152).

Hawks (1995, s. 371) manevi iyi oluşu, manevi gelişimin peşinde olma veya manevi olarak gelişime açık olma, yaşamda bir anlama sahip olma, aşkın bir güce inanıp o güçle ilişki kurma şeklinde tanımlamıştır. Manevi iyi oluş, bireyin hayatında istikrar, barış, uyum gibi özelliklerinin gelişmesini sağlayarak bireyin esenliğe ulaşmasını sağlarken, kişiler arasında da uyumlu bir ilişki oluşmasına ve böylece bireyin toplumsal olarak uyumlu davranışlar göstermesine yardımcı olur. Bu sayede kişinin benliğiyle, tanrısıyla ve yaşadığı toplumla olan yakınlık duygusunu artırmaktadır (Mahdian ve Ghaffari, 2016, s. 130138).

Manevi iyi oluş bireyleri yaşamın tüm alanlarında etkiler. Manevi iyi oluş noktasında zayıf olan bireyler ruhsal sorunlar, umutsuzluk duygusu, anlamsızlık, depresyon vb. durumları yaşayabilmektedirler (Westgate, 1996, s. 26-27). Ayrıca Westage (1996, s. 33) yapmış olduğu çalışmada manevi iyi oluş bağlamında görülen zayıflıkla depresyon arasında güçlü bir ilişki olduğunu ortaya koymuştur. Uğurluoğlu ve Erdem (2019, s.855) de bireylerin spiritüel iyi oluş düzeylerinin travma sonrası büyümeleri üzerindeki etkisini araştırdıkları çalışmalarında (benzer sonuçlara ulaşmışlardır. Aşkın bir gücün varlı̆̆ına inanan, dünya hayatının geçici olduğunu düşünen ve doğaya saygı duyarak onunla uyum içerisinde yaşamaya özen gösteren bireyler yaşadıkları travma sonrası diğer bireylere oranla kişilerarası ilişkilerini daha çok geliştirmişlerdir. Ayrıca bu kişiler yaşadıkları travma sonrasında kendilik algılarında, güçlüklerle mücadele noktasında, kendine güvenme konularında diğer bireylere oranla daha fazla gelişim göstermiş, yaşamın değerini anlayan ve yaşamlarının bir amacı olduğuna inanan bireyler haline gelmişlerdir.

Tüm bunlardan hareketle manevi iyi oluşu yüksek bireyler hayatı anlamlandırma, geleceğe umutla bakma, paylaşımcı olma, güçlükler karşısında dirayetli durma, kendine güvenme, hayatından memnun olma gibi konularda daha iyi bir noktadadir diyebiliriz. Bu durum bireylerin psikolojik ve ruhsal olarak iyi oluşlarını artırmaktadır ve depresyona girme ihtimallerini azaltabilmektedir. Manevi iyi oluşu yüksek bireyler üstün bir gücün varlığına inanarak "bunda da vardır bir hayır" düşüncesi ile travmatik deneyimlerden daha az zarar görebilmektedir (Uğurluoğlu ve Erdem, 2019, s. 837)

Kişinin manevi kimliği sergilediği davranışları, değer yargılarını, olaylar karşısındaki tutumunu, hayata bakış açısını şekillendirir ki bu da bize maneviyatın bireyin yaşamının tüm boyutlarıyla alakalı olan aşkın bir durum hali olduğunu anlatır (Baldwin, 2003, s. 24-32; Westgate, 1996, s. 27). Kitko (2001, s. 310) da çalışmasında maneviyatın bireylerin değer yargılarına, ahlaki tutumlarına, diğer insanlara ve çevreye karşı olan tutumlarına bağlı olduğunu ifade etmiştir. Yani bireylerin manevi iyi oluşları ile kişilik özellikleri etkileşim halindedir. Bu durum da bireylerin başlarına gelen travmatik olaylar sonucu yaşayacakları değişim ve dönüşüm üzerinde etkili olabilmektedir (Uğurluoğlu ve Erdem, 2019, s. 838).

\section{Yöntem}

Nicel araştırma paradigmasıyla yapılan bu çalışmada, evli bireylerde manevi iyi oluş, yaşamın anlamı ve ailede yılmazlık arasındaki yordayıc ilişkilerin belirlenmesi ve bu değişkenler arasındaki ilişkilerin yapısal eşitlik modeliyle sınanması hedeflenmiştir. Bu amaca yönelik olarak, genel tarama modelinin alt boyutlarından olan ilişkisel tarama modeline uygun olarak araştırma yapılmıştır.

Çok sayıda üyenin oluşturduğu bir evrende, evrenin tamamı yahut evrene ait bir grup örneklem üzerinden, evren hakkında genel bir kanıya ulaşılması amacıyla yapılan tarama araştırmaları, genel tarama modelleri olarak adlandırılmaktadır. Genel tarama modelleri, tekil veya ilişkisel taramalar yapma imkânı sağlamaktadır. Bu tarama modellerinden ilişkisel tarama modeli, iki veya daha fazla sayıda değişken arasındaki değişimin birlikte olup olmadığını ya da değişimin derecesini belirlemeyi amaç edinen araştırma modelleridir (Karasar, 2003, s. 92). 


\section{Çalışma Grubu}

Araştırma kullanılan ölçekler Ankara'da bulunan bir devlet okulunda 2018-2019 eğitim-öğretim yllında öğrenim gören ilkokul öğrencilerinin evli velileri ve okulda görev yapan evli öğretmenlerden gönüllü olanlara uygulanmıştır. 324'ü bulan veri sayısı geçersiz sayılan verilerden dolayı (eksik işaretleme, yarım bırakma, soruları anlayamama... vb.) 280'e düşmüştür.

Tablo 1. Katıllmollarn Cinsiyete Göre Dağgllmı

\begin{tabular}{lcc}
\hline Cinsiyet & Frekans & Yüzde \\
\hline Erkek & 87 & 31.9 \\
Kadın & 193 & 68.9 \\
Toplam & 280 & 100 \\
\hline
\end{tabular}

\section{Veri Toplama Araçları}

Kişisel Bilgi Formu. Demografik değişkenlere dair bilgi toplamak amacıyla, araştırmacı tarafindan geliştirilen kişisel bilgi formu kullanılmıştır. Bu formda katılımcıların yaş, cinsiyet, eğitim durumu, anne ve baba eğitim durumları ve maddi gelir düzeyinin belirlemesi amacıyla araştırmacının hazırladığı sorular yer almıştır.

Yașam Anlamı Ölçeği (YAÖ). Araștırmada yaşamın anlamını ölçmek için Steger, Frazier, Oishi ve Kaler (2006) tarafından geliştirilen ve Akın ve Taş (2011) tarafından uyarlaması yapılan Yaşam Anlamı Ölçeği kullanılmıştır. 7’li Likert (1-Benim için hiç doğru değil, 7-Benim için tamamen doğru) türü bir ölçme arac1 olan YAÖ 10 maddeden oluşmaktadır. Ölçek yaşamda mevcut anlam (1, 4, 5. 6 ve 9. maddeler, örneğin; Yaşamımı neyin anlamlı hale getireceğine ilişkin bir öngörüye sahibim) ve aranan anlam (2, 3, 7, 8 ve 10. maddeler, örneğin; Yaşamım için bir amaç ve misyon arıyorum) şeklinde iki alt boyuttan oluşmaktadır. Ölçekteki olası puanların ranj1 7 ile 70 arasında değissmektedir. Ölçekten alınan yüksek puanlar bireyin yaşam anlamına sahip olma düzeyinin yüksek olduğunu göstermektedir. Ölçeğin 9. Maddesi ters puanlanmaktadır. Ölçeğin iç tutarllık güvenirlik katsayıları mevcut anlam alt boyutu için 0,77 , aranan anlam alt boyutu için 0,83 ve ölçeğin bütünü için 0,81 olarak bulunmuştur. Dört hafta arayla elde edilen test-tekrar test güvenirlik katsayllarının ise mevcut anlam alt boyutu için 0,89 , aranan anlam alt boyutu için 0,92 ve ölçeğin bütünü için 0,94 olduğu saptanmıştır. Ölçeğin Türkçe formunun geçerlik ve güvenirlik puanları 0,70 ' den yüksek bulunduğundan güvenilirdir. Tüm bunlar göz önüne alınarak çalışmada ölçeğin kullanılması uygun bulunmuştur. YAÖ'nün ölçüt bağıntılı geçerliğini inceleyen araştırmalarda yaşam anlamının, yaşam doyumu, sevgi, dışa dönüklük, sorumluluk ile pozitif; korku, öfke, utangaçlık, depresyon ile negatif ilişkili olduğu görülmüştür.

Spiritüel İyi Oluş Ölçĕgi. Araştırmada Ekşi ve Kardaş (2017) tarafindan geliştirilen Spiritüel İyi Oluş Ölçeği kullanılmıştır. 5’li likert (1= Bana hiç uygun değil, 5= Bana tamamen uygun) türü bir ölçme arac1 olan ölçek 29 maddeden oluşmaktadır Spiritüel iyi oluş ölçeği aşkınlık, doğayla uyum ve anomi olmak üzere 3 alt boyut içermektedir. Ölçekten toplam puan alınmak istenirse anomi alt boyutundaki maddelerin ters puanlanması gerekmektedir. Ölçeğin alt boyutlarının güvenirlik katsayılarına bakıldığında; aşkınlık alt boyutuna ait Cronbach's Alpha değeri $\alpha=0,953$, doğayla uyum alt boyutu için $\alpha=0,864$ ve anomi alt boyutu için ise $\alpha=0,853$ olarak bulunmuştur. Bununla birlikte ölçeğin toplam Cronbach's Alpha değeri ise $\alpha=0,886$ olarak hesaplanmıştır. Spiritüel İyi Oluş Ölçeği’nin geçerlik ve güvenirlik çalışmaları, ölçeğin yetişkinlerin spiritüel iyi olma hallerini geçerli ve güvenilir olarak ölçme yeteneğine sahip olduğunu göstermektedir. Araştırmada manevi iyi oluş düzeylerini değerlendirmek üzere spiritüel iyi oluş ölçeğinin kullanılması uygun bulunmuştur.

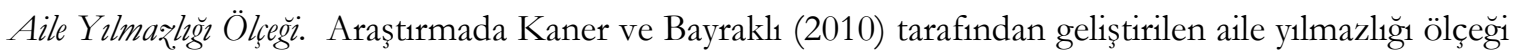
kullanılmıştır. 5'li likert (1-Beni hiç tanımlamıyor, 5-Beni çok iyi tanımlıyor) türü bir ölçme aracı olan ölçek 37 maddeden oluşmaktadır. Mücadecilik, yaşama bağlllık, öz-yetkinlik ve kontrol olmak üzere 4 alt boyuttan oluşmaktadır. Ölçekten alınan toplam puan ile aile yılmazlığı düzeyi belirlenmektedir. Bununla birlikte, her bir alt ölçekten alınan puanlarla da değerlendirme yapılabilmektedir. Tüm maddeler olumlu yönde ifade edilmiştir. Aile Yllmazlık Ölçeğinden yüksek puan almak anne-babalarda yılmazlığın yüksek olduğunu ifade etmektedir. Ölçeğin geçerlik ve güvenirlik çalısmalarına bakıldığında; Cronbach alfa ve iki yar1 güvenirlik katsayıları sırasıyla $0.54-0.91$ ve $0.53-0.87$ arasındadır. Test-tekrar test güvenirlik değerleri 0.33-0.80 arasında değişmekte olup tümünde anlamlıdır (Kaner ve Bayraklı, 2010). Araştırmada aile yılmazlığını değerlendirmek üzere aile yılmazlığı ölçeğinin kullanılması uygun bulunmuştur. 


\section{Verilerin Analizi}

Ölçekler, gönüllü olan katılımcılara araştırmacı tarafından uygulanmıştır. Çalışma grubu 20 ve 50 yaş arası evli bireylerden oluşmaktadır. Uygulama öncesi katılımcılar, araştırmanın amacı ile ölçeğin nasıl uygulanacağı konularında bilgilendirilmiştir. Ölçeklerin uygulanmasında gönüllülük ilkesi baz alınmıştır. Toplam 324'e ulaşan veri sayısı, geçersiz sayılan veriler sebebiyle (eksik işaretleme, yarım bırakma vb.) 280'e düşmüştür. Uygulamalar yaklaşık 20 ila 30 dakika sürmüştür.

Araşıtırmada evli bireylerde manevi iyi oluş, yaşamın anlamı ve ailede yılmazlık arasındaki ilişkilerin belirlenmesi ve bu ilişkilerin yapısal eşitlik modeli ile sınanması amacıyla yapısal eşitlik modeli analizi yapılmıştır. Yapısal eşitlik modellemesi, kuramsal bir modeli analiz etme amacıyla gözlemlenen değişkenler arasındaki karşılıklı ve nedensel ilişkileri ortaya çıkaran istatistiki bir yaklaşım olarak nitelendirilebilir (Shumacker ve Lomax, 2004). AMOS 19 programı ile analiz yapılmıştır. Araştırmada toplanan verilerin yüzde ve frekans hesapları için SPSS 18 paket programı kullanılmıştır.

\section{Bulgular}

Elde edilen son modelde $(\mathrm{X} 2 / \mathrm{sd}=3.01, \mathrm{p}<.001)$ üç exogenus, değerler (aşkınlık, doğayla uyum ve anomi) altı endogenous (anlamın aranması, anlamın varlığı, kontrol, yaşama bağlllık, öz yetkinlik ve mücadelecilik) veri bulunmaktadır. Modelde gösterilmiş olan tüm yolların istatistiksel olarak anlamlı bulunduğu görülmüştür. The Tucker-Lewiscoefficient fit index (TLI), The Bentler-Bonettnormed fit index (NFI) ve diğer uyum indeksleri modelde oldukça iyi bir uyumluluk olduğunu göstermektedir. (Tablo-1). Modelde görülen endogenous verileri arasındaki iki yönlü korelasyonların her birinin yüksek değerlere sahip olduğu ve istatistiki olarak anlamlı olduğu görülmektedir. Bu anlamlı durum, değerler ölçeğinin alt boyutlarından oluşan korelasyon değerlerinden de etkilenmektedir.

Tablo 2. Yapısal Eşitlik Modelinin Uyumuna İlişkin Istatistiksel Değerler

\begin{tabular}{cccc}
\hline Ölçüm & İy Uyum & Kabul Edilebilir Uyum & Modelin Uyum İndeksi Değerleri \\
\hline (X2/sd) & $\leq 3$ & $\leq 4-5$ & 3.01 \\
RMSEA & $\leq 0.05$ & $0.06-0.08$ & 0.06 \\
SRMR & $\leq 0.05$ & $0.06-0.08$ & 0.05 \\
NFI & $\geq 0.95$ & $0.94-0.90$ & 0.95 \\
CFI & $\geq 0.97$ & $\geq 0.95$ & 0.95 \\
GFI & $\geq 0.90$ & $0.89-0.85$ & 0.94 \\
AGFI & $\geq 0.90$ & $0.89-0.85$ & 0.92 \\
TLI & $\geq 0.95$ & $0.94-0.90$ & 0.96 \\
\hline
\end{tabular}

Tablo 1'de gösterilen uyum değerlerini incelediğimizde, $\mathrm{X} 2 / \mathrm{sd}=3.01, \mathrm{RMSEA}=0.06, \mathrm{SRMR}=0.05$, $\mathrm{NFI}=0.95, \mathrm{CFI}=0.95$, GFI $=0.94, \mathrm{AGFI}=0.92$ ve TLI $=0.96$, olduğunu görmekteyiz. Modelin genelinde istenen düzeyde uyum değerlerinin ortaya çıktığ1 görülmektedir (Bollen, 1989; Browne ve Cudeck, 1993; Byrne, 2010; Hu ve Bentler, 1999; Kline, 2011; Tanaka ve Huba, 1985). Analiz edilen tek faktörlü model Şekil 1'de gösterilmektedir. Modelde gösterilen bütün yolların 0.01 düzeyinde anlamlı olduğu görülmektedir.

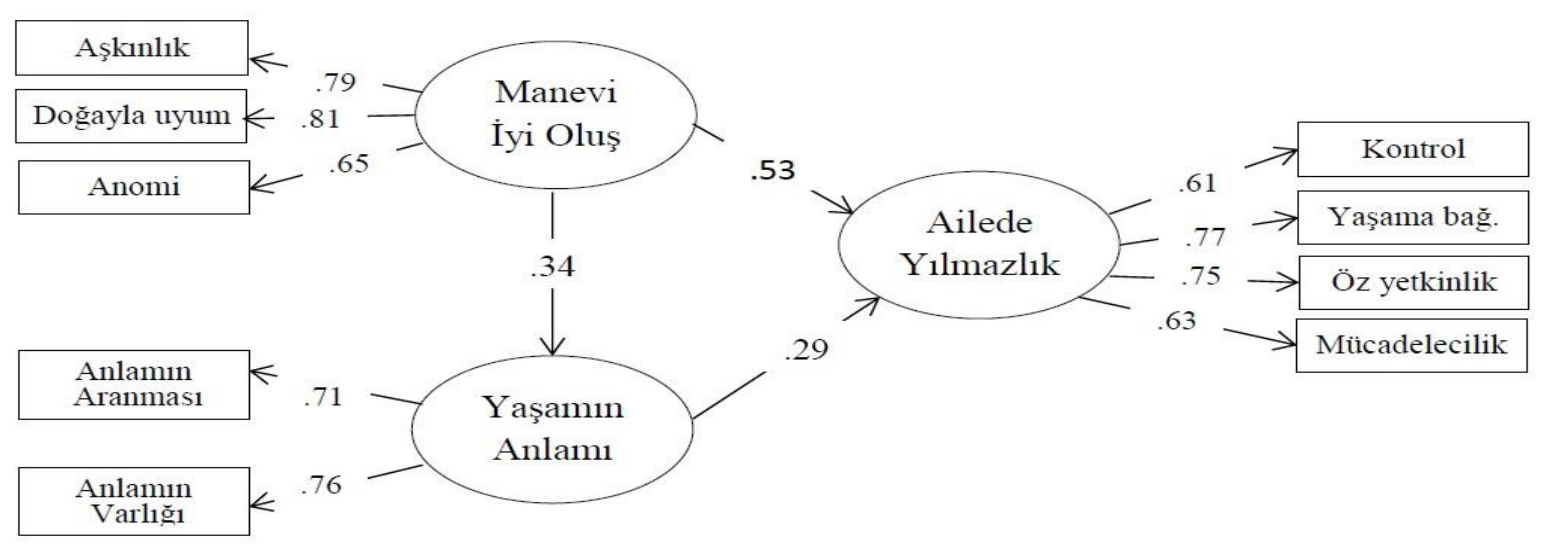

Şekil 1. Modele İliskin Yol Analiri 


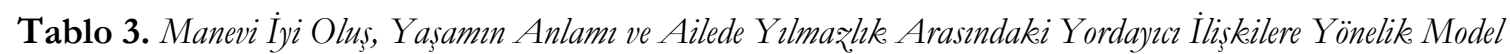

\begin{tabular}{llccc}
\hline \multicolumn{1}{c}{ Yordayıcı Değişken } & Bağımlı Değişken & Standardize $\beta$ & Standart Hata & Kritik Değer \\
\hline Manevi İyi Oluş & Ailede Yllmazlık & 0.53 & 0.11 & $5.91^{* *}$ \\
Manevi İyi Oluş & Yaşamın Anlamı & 0.34 & 0.17 & $3.63^{* *}$ \\
Yaşamın Anlamı & Ailede Yllmazlık & 0.29 & 0.22 & $3.08^{*}$ \\
\hline
\end{tabular}

a Toplam etki $=$ Doğrudan etki + Dolaylı etki, ${ }^{*} p<0.01,{ }^{*} p<<0.05$.

Tablo incelendiğinde, ailede yılmazlığı etkileyen bağımsız değişkenin $(\mathrm{t}=5.91, \mathrm{p}<0.01)$ manevi iyi oluş olduğu görülmektedir. Bu faktöre dair bağlantı katsayı değeri $\beta=0.53$ olarak ortaya çıkmıştır. Tabloya göre, evli bireylerde manevi iyi oluş ile ailede yılmazlık arasındaki yordayıcı ilișkiler araștıııldığında, pozitif yönde doğrusal ve anlamlı bir ilişki tespit edilmiştir. Başka bir ifadeyle elde edilmiş olan sonuçlar, evli bireylerin manevi iyi oluş düzeyleri arttıkça ailede yılmazlıklarının da artacağını göstermektedir.

Modelde yaşamın anlamı değişkenine etki eden değişkenin $(\mathrm{t}=3.63, \mathrm{p}<0.01)$ manevi iyi oluş olduğu görülmüş ve bu faktöre dair bağlantı katsayı değeri $\beta=0.34$ olarak ortaya çıkmıştır. Evli bireylerin manevi iyi oluşları ile yaşamın anlamı arasındaki yordayıcı ilişskiler incelendiğinde, pozitif yönlü doğrusal ve anlamlı bir ilişkinin var olduğu görülmektedir. Başka bir ifadeyle elde edilen sonuçlar, evli bireylerin manevi iyi oluş düzeyleri arttıkça yaşamın anlamının da arttı̆̆ını göstermektedir.

Modelde ailede yllmazlık değişkenine etki eden değişkenin $(t=3.08, \mathrm{p}<0.01)$ yaşamın anlamı değişkeni olduğu görülmüş ve bu faktöre dair bağlantı katsayı değeri $\beta=0.29$ olarak ortaya çıkmıştır. Evli bireylerde yaşamın anlamı ile ailede yılmazlık düzeyleri arasındaki yordayıcı ilişkiler incelendiğinde, pozitif yönlü doğrusal ve anlamlı bir ilişkinin var olduğu görülmektedir. Başka bir ifadeyle elde edilen sonuçlar, evli bireylerin yaşamlarının anlamı arttıkça ailede yılmazlıklarının da artacağını göstermektedir.

\section{Tartışma, Sonuç ve Öneriler}

\section{Tartısma}

Bu bölümde evli bireylerde manevi iyi oluş, ailede yılmazlık ve yaşamın anlamı arasındaki yordayıc1 ilişkilerin araştırılması ile elde edilen bulgular tartışılmış ve yorumlanmışıır.

Araştırmanın sonuçlarına göre ailede yılmazlık değiş̧kenine etki eden en önemli değişkenin manevi iyi oluş olduğu belirlenmiştir. Evli bireylerde manevi iyi oluş ve ailede yılmazlık değişkenleri arasındaki yordayıcı ilişkilere bakıldığında, pozitif yönde doğrusal ve anlamlı bir ilişki olduğu görülmüştür. Bir başka ifade ile elde edilen bulgular, evli bireylerin manevi iyi oluş düzeyleri arttıkça aile yılmazlıklarının da artacağını göstermektedir. Literatürde evli bireylerin aile yılmazlıklarının ve manevi iyi oluşlarının birlikte ele alındığı bir araştırmaya rastlanmamıştır. Aile yllmazlı̆̆ının yeni bir kavram olması ve aile yılmazlı̆g konusuna fazla ilgi olmaması sebebiyle bu bağlamda yapılmış araştırmalar oldukça sınırlıdır. Yapılan çalısmalar genellikle çocuklarında gelişimsel yetersizlik bulunan ailelerin yılmazlık düzeylerine ilişkindir ve bu çalışmalar da çok sınırlı düzeyde kalmışlardır.

Benzies ve Mychasiuk (2009, s. 103-114) aile yılmazlı̆ı̆nı etkileyen temel koruyucu faktörleri araştırdıkları çalışmalarında, aile yılmazlığını değerler, maneviyat-inanç yapısı, özgüven, etkili başa çıkabilme becerileri gibi değişkenlerin etkilediğini belirtmiştir. Şahin, Aydın, Sarı, Kaya ve Pala, (2012, s. 827-836) yaptıkları araştırmada; umut ve yaşamda anlamın, yılmazlık ile yüksek ilişki gösteren öznel iyi oluşun anlamlı birer yordayıcısı olduğunu ifade etmişlerdir. Özbay ve Aydoğan (2013, s. 129-146), çocuğu engelli olan ailelerde aile yılmazlığını nitel araştırma yöntemi kullanarak incelemiştir. Ailelerin yılmazlıklarına katkı sağlayan en önemli etkenlerden birinin de maneviyat olduğu sonucuna ulaşmışlardır. Akdoğan ve Yalçın (2017, s. 174-197) yaptıkları araştırmada lise öğrencilerinin psikolojik dayanıklılık alt boyutları (aile desteği, akran desteği, okul desteği, uyum, mücadele azmi ve empati) puan ortalamalarıyla; öznel iyi oluşun alt boyutlarının (aile doyumu, önemli diğer kişilerle iletişimde doyum, yaşam doyumu ve olumlu duygular) puan ortalamaları arasında pozitif yönde ve anlamlı bir ilişki olduğu sonucuna ulaşmışlardır. Mahdian ve Ghaffari (2016, s. 130) kanser hastalarının katılımı ile yapmış oldukları araştırmada; spiritüel iyi oluş ile psikolojik dayanıklılık arasında olumlu yönde anlamlı bir ilişki bulunmuştur. İkizer'in (2014) Van depreminde hayatta kalanlar ile yaptı̆̆ı nitel ve nicel çalışma bulguları, özellikle nitel çalışmada dindarlık ve dini başa çıkmanın, yılmazlık için çok önemli bir etken olduğunu ortaya çıkarmıştır. Elde edilen bulgular, dini inanç ve uygulamaların hayatta kalanların psikolojik sağlığı ve afetler sonrası adaptasyonlanı için koruyucu rol oynadığını dolayısıyla yılmazlı̆̆ı artırdığını göstermiştir. 
Bayraklı, Kaner ve Güzeller (2011, s. 69) yllında ana babalarının yılmazlık algilarını inceledikleri araştırmalarında, çocukları normal gelişim gösteren anne-babaların yetersizliği olan çocuklara sahip annebabalara göre kendilerini daha yılmaz bireyler olarak algıladıklarını, çocuklarında kronik sorunlar bulunan ana babaların çocukları normal gelişim gösteren anne-babalara göre kendilerini daha az mücadeleci ve daha az iyimser algıladıklarını belirlemiştir. Bhana ve Bachoo (2011, s. 131-139) araştırmalarında bireylerin sahip olduğu değerler ve inanç sistemlerinin; bireysel yılmazlıklarını ve aile yılmazlığını etkilediğini ortaya koymuştur. Klerk ve Greeff (2011, s. 414-424) görme engelli çocuğa sahip olan ailelerin yilmazlıklarını inceledikleri çalışmalarında ailenin sahip olduğu tutumların, yakınlığın ve kader/ dini inancın onların yılmazlıklarına etki eden içsel koruyucu faktörler olduğunu belirlemişlerdir. Çocuğunda Otizm Spektrum Bozukluğu (OSB) olan ailelerde uyum ve adaptasyonu araştıran Kapp ve Brown (2011, s. 459-464) OSB'ye ilişkin teşhisi ve beraberindeki zorluklardan kurtulmalarını sağlayan yılmazlık faktörleri tanımlamıştır. Niteliksel analizden elde edilen bulgular neticesinde ailenin dayanıklılı̆̆1, problem çözme şekli, aile zamanı ve rutinlerinin önemli yılmazlık kaynakları olduğu sonucuna ulaşılmıştır. Marsh, Beard ve Adams (1999, s. 13-20) hemşirelerde manevi iyi oluş ve psikolojik dayanıkllığın, iş stresi ve tükenmişlik üzerinde aracıllk etkisini incelemek için çalışma yapmışlardır. Elde edilen verilere göre manevi iyi oluşun psikolojik dayanıklılık ve tükenmişlik üzerinde doğrudan aracı etkisi bulunmaktadır. Çalışmanın bir diğer sonucunda yaşamda anlam değişkenine etki eden değişkenin manevi iyi oluş olduğu belirlenmiştir.

Evli bireylerin manevi iyi oluşları ile yaşamın anlamı arasındaki yordayıcı ilişkiler incelendiğinde, pozitif yönlü doğrusal ve anlamlı bir ilişkinin var olduğu görülmektedir. Bir başka ifadeye göre bu sonuç, evli bireylerin manevi iyi oluş düzeyleri arttıkça yaşamın anlamının arttığını göstermektedir. İnsanlarda maneviyata ait değerler yaşamı anlamlandırılmasında önemli rol oynamaktadır (Telatar ve Özcebe, 2004, s. 162-165). Yaşamda anlam kavramı, iyi oluşa ilişkin pek çok kuramın temel ögesidir (Ryff, 1989, s. 10691081). Bu açıdan ele alındığında yaşamda anlamın varlığının manevi iyi oluş ile pozitif ilişki içinde olması beklenen bir durumdur ve yapılan araştırmaların sonuçları da bu durumu destekler niteliktedir.

Literatürü incelediğimizde manevi iyi oluş kavramı ile yapılan çalışmaların sınırlı sayıda olduğunu görürüz. Manevi iyi oluş, iyi oluş kavramının içinde yer almaktadır. İyi oluş kavramının içeriği (psikolojik, fiziksel, sosyal, finansal, çevresel, entelektüel, manevi iyilik hali) oldukça geniştir (Doğan, 2016). Manevi iyi oluş kavramına yönelik çalışmalar din ve sağlık alanında yoğunlaşmıştır. Psikoloji alanında yapılan çalışmalar ise daha çok psikolojik iyi oluş ve öznel iyi oluş kavramları üzerinedir.

Tillich (2014) maneviyatı anlam duygusu ile açıklamıştır. Steger vd. (2008, s. 199-228), iyi oluş ile anlamın varlığ arasında anlamlı ve pozitif bir ilişki bulurken, Şahin vd. (2012, s. 830) yllında yaptıkları çalışmada benzer şekilde bireylerde yaşamda anlam düzeyleri arttıkça öznel iyi oluş düzeyinin yükseldiğini bulmuşlardır. Carson ve Green (1992, s. 209) tarafından (HIV+) virüsü taşıyan 100 katılımcı üzerinde yapılan araştırmada manevi iyi oluşun alt boyutu olan varoluşsal iyi oluş ve psikolojik dayanıklılık arasında anlamlı ilişki olduğu; hayatlarında anlam ve amaç bulabilen, manevi iyi oluşu yüksek olan bireylerin daha dayanıklı olduğu belirlenmiştir. Sims (2000, s. 1330) tarafından yapılan benzer bir araştırma da psikolojik dayanıklllkk ve manevi iyi oluşun tükenmişlik ile negatif yönde; manevi iyi oluşun alt boyutu olan varoluşsal iyi oluş ve psikolojik dayanıklılığın pozitif yönde ilişkili olduğunu göstermektedir. Jafari, vd. (2010a, s. 1477) çalışmalarında manevi iyi oluş ile ruh sağlığı arasında anlamlı bir ilisski olduğunu; dini ve varoluşsal iyi oluşun ruh sağlığını önemli ölçüde yordadığını tespit etmiştir. Kitko (2001, s. 310) çalışmasında bireylerin hayatlarında meydana gelen anlam veremedikleri inişli çıkışlı dönemlerinde dini inançlarının, aşkın bir güce inanma durumunun bu dönemleri atlatma konusunda bireylere yardımcı olduğunu ifade etmiştir. Westgate'in (1996, s. 33) araştırması spiritüel iyi oluş bağlamında görülen zayıflıkla depresyon arasinda güçlü bir ilişki olduğunu ortaya koymuştur. Dursun (2019, s.69) evli ve bekâr bireylerin yaşamın anlamı ve maneviyat düzeyleri arasındaki ilişkinin incelenmesi konulu çalışmasında hem evli hem de bekârlarda iki değişken arasında pozitif yönde anlamlı bir ilişki olduğunu belirlemiştir. Shahidi ve Hamdie (2002) yaptıkları araştırmalar sonucunda, spiritüel iyi oluş düzeyi yüksek olan insanların daha sağlıklı bir hayat tarzına sahip olduklarını, daha mutlu olduklarını ve hayatlarından daha fazla memnun olduklarını göstermiştir (Akt: Mahdian ve Ghaffari, 2016, s. 130-138). Yapılan araştırmalar iyi oluş ile ilgili kavramların yaşamda anlamın bulunması ile yakından ilişkili olduğunu göstermiştir (Fry, 2000; Jia-Yan, Wong, Jobert ve Chan, 2008; Scannell, Allen ve Burton, 2002; Steger ve Kashdan, 2000; Zika ve Chamberlain, 1992; Akt: Demirbaş, 2010, s. 64).

Çalışmanın en son sonucunda ailede yılmazlık değişkenine etki eden değişkenin yaşamın anlamı değişkeni olduğu görülmüştür. Evli bireylerin yaşamının anlamı ile ailede yılmazlık düzeyleri arasındaki yordayıcı ilişkiler incelendiğinde, pozitif yönlü, doğrusal ve anlamlı bir ilişkinin var olduğu görülmektedir. 
Bir başka ifadeye göre elde edilen sonuçlar, evli bireylerin yaşamlarının anlamı arttıkça ailede yılmazlıklarının da arttığını göstermektedir.

Seligman (2007, s. 23-40) olumlu duygu ve yaşamı anlamlı bulmanın bireyin acıya ve zor koşullara dayanabilme gücünü arttırdığını ifade eder. Demirbaş ve Keklik (2011, s. 3-5), araştırmalarında alınan yılmazlık ve yaşamda anlam arasındaki pozitif ilişki bulmuşlardır. Demirbaş'in (2010, s. 62) araştırmasında yaşamda anlam ile yilmazlık arasında, yaşamda anlamın alt boyutları olan yaşamda anlamın varlığı ve aranması, yılmazlığın iki alt boyutu olan toparlanmaya yönelik kişisel güçlü yönler ve kendine yönelik olumlu değerlendirmeler ile pozitif yönde düşük düzeyde ilisski bulunmuştur. Parlak (2014, s. 72) Kredi Yurtlar Kurumu'nda kalan kız öğrencilerle ilgili yaptığı araştırmada psikolojik dayanıklılık ile yaşamda anlam arasında olumlu yönde anlamlı bir ilişki olduğunu belirlemiştir. Yıkılmaz ve Demir-Güdül (2015, s. 308) araştırmalarında üniversite öğrencilerinin yaşamda anlam düzeylerinin yılmazlıkla yakından alakalı bir kavram olan yaşam doyumunun anlamlı bir yordayıcısı olduğunu belirlemişlerdir. Frankl, Auschwitz toplama kampında kaldığı sürede yaşamında bir anlam duygusuna sahip olan kişilerin güç koşulların üstesinden gelebildiklerine şahit olmuştur. Herhangi bir amaç duygusu olan kişilerin yaşamak için karşılaştıkları zorluklarla baş etmeye çabaladıklarını, herhangi bir amacı olmayan kişilerin ise yaşamak için dahi hiçbir çaba sarf etmediklerini gözlemlemiştir (Frankl, 2013). Mascaro ve Rosen (2006, s. 168) y1lında yaptıkları araştırmada yaşamda anlamın varlığının strese karşı koruyucu bir etkisi olduğunu bulmuştur. Masten ve Reed (2002, s. 74-88) ise yaşamda anlamın varlığını, çocuklar ve gençler için koruyucu bir faktör olarak belirlemişlerdir. Southwick ve Charney (2012) idealler, değerler, sevilen insanlar ve yaşam anlamının bireyin dayanıklılık rezervleri olduğunu, bireye güç ve cesaret verdiğini ifade etmişlerdir. Pattakos (2010) travmatik yaşantılarla baş etmede ve yılmazlığ artırmada yaşam anlamının önemini vurgulamıştır. Ekşi, Boyalı ve Ümmet' in (2018) 338 öğrenci üzerinde yaptıkları araştırmada, manevi iyi oluşun bireylerin psikolojik dayanıklılıkları üzerinde önemli yordayıcı etkileri olduğu ortaya çıkmıştır. Öğretmen adaylarında yaşamda anlam ve manevi iyi oluş düzeyleri arttıkça psikolojik dayanıklılık düzeyinin de arttığı bulunmuştur

Tüm bu bulgular dolaylı ya da direkt olarak bu araştırmanın sonuçlarını destekler niteliktedir.

\section{Sonuç}

1. Evli bireylerde ailede yılmazlığı etkileyen en önemli bağımsız değişkenin manevi iyi oluş olduğu görülmektedir. Evli bireylerin manevi iyi oluş ile ailede yılmazlık düzeyleri arasındaki yordayıc1 ilişkiler araştırıldığında, pozitif yönde doğrusal ve anlamlı bir ilişki tespit edilmiştir. Başka bir ifadeyle elde edilmiş olan sonuçlar doğrultusunda, evli bireylerin manevi iyi oluş düzeyleri arttıkça ailede yılmazlıklarının da artacağı gözükmektedir.

2. Evli bireylerde yaşamın anlamı değişkenine etki eden en önemli değişkenin) manevi iyi oluş olduğu belirlenmiştir. Evli bireylerin manevi iyi oluşları ile yaşamın anlamı arasındaki yordayıcı ilişkiler incelendiğinde, pozitif yönlü doğrusal ve anlamlı bir ilişkinin var olduğu görülmektedir. Başka bir ifadeyle elde edilen sonuçlar, evli bireylerin manevi iyi oluş düzeyleri arttıkça yaşamın anlamının arttı̆̆ını göstermektedir.

3. Evli bireylerde yllmazlık değişkenine etki eden en önemli değişkenin yaşamın anlamı değiş̧keni olduğu görülmüştür. Evli bireylerin yaşamının anlamı ile ailede yılmazlık düzeyleri arasındaki yordayıcı ilişkiler incelendiğinde, pozitif yönlü doğrusal ve anlamlı bir ilişkinin var olduğu görülmektedir. Başka bir ifadeyle elde edilen sonuçlar, evli bireylerin yaşamlarının anlamı arttıkça ailede yılmazlıklarının da arttı̆̆ını göstermektedir.

\section{Öneriler}

1. Literatür incelendiğinde bu araştırmada konu edinilen ailede yllmazlık, yaşamda anlam ve manevi iyi oluş değişkenlerini bir arada bulunduran bir araştırmaya rastlanmamıştır. Ülkemizde yılmazlık ve yaşamda anlam ile ilgili araştırmaların görece daha yaygın olduğu görülse de, alanyazını incelediğimizde maneviyat/spiritüellik/manevi iyi oluş kavramları ile ilgili yapılmış çalışmalara az rastlanmış, bu alandaki çalışmaların hemşirelik ve din psikolojisi alanında yoğunlaştı̆̆ belirlenmiştir. Manevi iyi oluş ile ilgili yapılacak yeni çalışmalar bu kavramın daha iyi anlaşılmasını sağlayacaktır.

2. Manevi iyi oluş kavramının öneminin ilerleyen süreçlerde daha da artacağ1 ön görülmektedir. Toplumsal ve bireysel bazda iyi oluş için manevi iyi oluş ile ilgili çalışmaların toplum bazında yaygınlaştırılması önemli gözükmektedir. 
3. Manevi iyi oluşun eğitim alanındaki yeri, eğitimde nasıl kullanılabileceği ve diğer psikolojik değişkenlerle ilişkisinin inceleneceği yeni araştırmaların hem literatüre katkı sağlayacağı hem de daha yılmaz ve hayatında anlam bulan bireyler yetişmesine katkı sağlayacağı düşünülmektedir.

4. Yılmazlık ve yaşamda anlamın varlığının bireyin ruhsal sağlığındaki önemi aşikârdır. Toplum bazında artan ruhsal sıkıntıları göz önüne alarak, yılmazlık ve yaşamda anlam ile ilişkili değişkenlerin incelenmesi ve tespit edilmesinin önleyici ruh sağlı̆̆ hizmetlerinin gelişimi noktasında önemli olduğu görülmektedir.

5. Artan boşanma oranlarını baz alarak, evli bireylerin manevi iyi oluşlarını ve yaşamda anlam düzeylerini artırabilecek ortamların ve çalışmaların, aile yılmazlığını artırarak zorluklar karşısında daha dayanıklı olmalarını ve aile birliğini korumalarını sağlayabilecekleri düşünülmektedir.

6. Aile yılmazlığı kavramının önemi göz önünde bulundurularak bu kavramla ilgili daha fazla çalışma yapılmasının hem alan yazına katkı sağlayacağı hem de aile temelli çalışmalarda kullanılabileceği düşünülmektedir.

7. Alan yazındaki boşluğa bakıldığında olumlu psikolojik özellikleri yordama potansiyeline sahip bu değişkenlerle yapılacak çalışmalara ihtiyaç olduğu fark edilmektedir.

8. Araştırma alanımızla ilgisi bulunan kurumlanın (Milli Eğitim Bakanlı̆̆ı, Aile ve Sosyal Politikalar Bakanlı̆̆1, Sosyal Hizmetler ve Çocuk Esirgeme Kurumu, Diyanet İşleri Başkanllğı vs.), manevi iyi oluş, aile yılmazlığı ve yaşamda anlam konuları hakkında uygulamaya dönük çalışmalar yaptırmalarının son derece faydalı olacağı varsayılmaktadır.

9. Bu araştırmanın çalışma grubu çocukları Ankara'daki bir okulda eğitim gören evli veliler ve bu okulda görev yapan evli öğretmenler ile sınırlıdır. Konu ile ilgili daha geniş bilgi sahibi olmak için farklı şehirlerdeki, bölgelerdeki evli bireylere uygulanmasının faydalı olacağı düşünülmektedir.

\section{Etik Beyan}

"Evli Bireylerde Manevi İyi Oluş, Ailede Yılmą̧lk ve Yaşamın Anlamı Arasındaki Yordayıcı Illişkiler" başlıklı çalışmanın yazım sürecinde bilimsel kurallara, etik ve alıntı kurallarına uyulmuş; toplanan veriler üzerinde herhangi bir tahrifat yapılmamış ve bu çalışma herhangi başka bir akademik yayın ortamına değerlendirme için gönderilmemiştir. Gerekli olan etik kurul izinleri Necmettin Erbakan Üniversitesi Sosyal ve Beşeri Bilimler Bilimsel Araştırmalar Etik Kurulu'nun 19.02.2021 tarih ve 02 saylı toplantısında alınmıştır.

\section{Kaynakça}

Acar, H. (2014). Manevi iyi oluş ile dindarlık arasındaki ilişki üzerine bir değerlendirme. Cumburiyet Üniversittesi İlabiyat Fakïltesi Dergisi, 18(2), 391-412.

Adams, T., Bezner J. ve Steinhardt M. (1997). The conceptualization and measurement of perceived wellness: Integrating balance across and within dimensions. American Journal of Health Promotion, 11(3), 208-218

Adler, A. (2012). Yaşamin anlam ve amact (10. Basım). İstanbul: Say.

Akdoğan, B. ve Yalçın, S. (2018). Lise öğrencilerinin psikolojik dayanıklılık ve çatışma çözme davranışlarının öznel iyi oluşların yordaması. Mehmet Akif Ersoy Üniversitesi Eg̈itim Fakültesi Dergisi, 46, 174-197

Akın, A. ve Taş, İ. (2015). Yaşam anlamı ölçeği: Geçerlik ve güvenirlik çalışması. Electronic Turkish Studies, 10(3), 2736.

Akıncı, A. (2005). Hayata anlam vermede dini değerlerin ve din öğretiminin rolü. Değerler Ë̆itimi Dergisi, 3(9), 7-24.

Akkoyun, F. (2005). Gestalt terapi: Büyüme ve gelisme gücümü̃ün harekete geçisi. Ankara: Nobel Yayınc1lik.

Altıntaş, E. ve Gültekin, M. (2005). Psikolojile danısma kuramlar. Aktüel Yayınları.

Arda, Ş. (2011). Kanser hastalarnnda yaşamda anlamnn incelenmesi (Yüksek Lisans Tezi). İstanbul Üniversitesi Sağllk Bilimleri Enstiüsü, İstanbul.

Bahadır, A. (2009). Hayatın anlam kazanmasmda psiko-sosyal faktörler ve din (Doktora Tezi). Uludağ Üniversitesi Sosyal Bilimler Enstitüsü, Bursa.

Baldwin, D. C. (2003). Spiritual identity: Evaluating a seminar on spiritual identity on spiritual wellness (Doktora Tezi). Southern Christian University, Oklahoma.

Battista, J. ve Almond, R. (1973). The development of meaning in life. Psycbiatry, 36(4), 409-427.

Bayrakl, H. (2010). Zibinsel engelli ve engelli olmayan çocuğa sabip annelerde yllma rhğga etki eden değgiskenlerin incelenmesi (Yüksek Lisans Tezi). Ankara Üniversitesi Eğitim Bilimleri Enstitüsü, Ankara.

Bayraklı, H. ve Kaner, S. (2010). Zihinsel engelli ve engelli olmayan çocuğa sahip annelerde yllmazlığa etki eden değişkenlerin incelenmesi. 20. Özel Ë̆gitim Kongresi. Ögretmen Yețștirme: Bildiri Özetleri, Ankara: Kök Yayıncllı, 7071.

Begun, A. L (1993). Human behavior and the social enviroment: The vulnerability, risk and resilience model. Journal of Social Work Education, 29(1), 26-35.

Benzies, K. ve Mychasiuk, R. (2009). Fostering family resiliency: A review of the key protective factors. Cbild \& Family Social Work, 14, 103-114. 
Bhana, A. ve Bachoo, S. (2011). The determinants of family resilience among families in low and middle-income contexts: A systematic literature review. South African Journal of Psychology, 41(2), 131-139.

Bollen, K. A. (1989). A new incremental fit index for general structural equation models. Sociological Methods and Research, 17(3), 303-316.

Browne, M. W. ve Cudeck, R. (1993). Alternative ways of assessing model fit. Sage Focus Editions, 154, 136-136.

Byrne, B. M. (2010). Structural equation modeling with AMOS: Basic concepts, applications, and programming (2 ${ }^{\text {nd }}$ Edition). New York: Taylor and Francis.

Camus, A. (1998). Sisifos söyleni (Çev: T. Yücel). İstanbul. Can Yayınları.

Carson, V. B. ve Green, H. (1992). Spiritual well-being: A predictor of hardiness in patients with acquired immunodeficiency syndrome. Journal of Professional Nursing, 8(4), 209-220.

Chia, B. H., Chia, A. ve Tai, B. C. (2008). Suicide letters in sangapore. Archives of Suicide, 12, 74-81.

Cihan-Güngör, H. (2014). Aile y1lmazlığ1 değerlendirme ölçeğinin Türkçeye uyarlanması: Geçerlik ve güvenirlik çalışması. Literatüre and History of Turkish or Turkic, 9(5), 497-512.

Corey, G. (2008). Psikolojik danısma, psikoterapi kuram ve uygulamalar. Tuncay Ergene (Ed.). Ankara: Mentis

Das, A. K. (1998). Frankl and the realm of meaning. Journal of Humanistic Education \& Development, 36(4), $199-211$.

Demirbaş, N. ve Keklik, İ. (2011). Üniversite öğrencilerinin yaşamda anlam ve yılmazlıkları arasındaki ilişki. XI. Ulusal Psikolojik Danısma ve Rehberlik Kongresi (3-5 Ekim 2011), 3-5.

Demirbaş, N. (2010). Yaşamda anlam ve yılmað̧lık. Hacettepe Üniversitesi Sosyal Bilimler Enstitüsü, Ankara.

Doğan, T. (2016). Kendini Toparlama Gücü: Psikolojik Sağlamlık. https://www.tayfundogan.net/2016/10/20/kendini-toparlama-gucu-psikolojik-saglamlik/ (Erişim 01.08.2020)

Dursun, N. (2019). Evli ve bekar bireylerin yaşamm anlame ve maneviyat düzeyleri arasindaki ilişkinin incelenmesi. İstanbul Sabahattin Zaim Üniversitesi.

Dursun, P. (2012). Yaşamın anlamı, iyimserlik, umut ve başa çıkma stillerinin öznel iyi oluş üzerindeki rolü (Doktora tezi). Orta Doğu Teknik Üniversitesi Sosyal Bilimler Enstitüsü, Ankara.

Düzgüner, S. (2013). Maneviyat algısı ve diğerkâmlıkla iliş̧kisi (kan bă̆ģş örneğinde Türkìye ve Amerika karşılaştırmalı nitel bir araștırma (Doktora Tezi). Necmettin Erbakan Üniversitesi Sosyal Bilimler Enstitüsü, Konya.

Düzgüner, S. (2016). Nereden çıtı bu maneviyat: Manevi bakımın temellerine ilişkin kültürlerarası bir analiz. Manevi Damısmanlık ve Rehberlik. Ed. Ali Ayten, Mustafa Koç, Nuri Tinaz, 1, 17-44.

Ekşï, H. ve Kardaş, S . (2017). Spiritual well-being: Scale development and validation. Spiritual Psychology and Counseling, 2(1), 73-88.

Ekşi, H., Boyalı, C. ve Ümmet, D. (2019). Öğretmen adaylarının spiritüel iyi oluş ile yaşamda anlam değişkenlerinin psikolojik dayanıklılığ1 yordaması: Bir yapısal eşitlik modeli (YEM) denemesi. Kastamonu Ĕ̈itim Dergisi, 27(4), 1695-1704.

Eminağaoğlu, N. (2006). Güc koşullarda yaşayan sokak çocuklarnnda dayanıklllk (sağlamlık) (Doktora Tezi). Ege Üniversitesi Sosyal Bilimler Enstitüsü, İzmir.

Frankl, V. E. (1996). Duyulmayan anlam çı̆ğğg (2. Basım). Ankara: Öteki.

Frankl, V. E. (2013). Insanın anlam arayısı (11. Basım). İstanbul: Okuyan Us.

Geçtan, E. (2007). Varoluş ve psikeiyatri (7. Basım). İstanbul: Metis Yayınları.

Gizir, C. A. (2004). Akademic resilience: An Investigation ofprotective factors contributing to the academic achievement of eighth grade students in poverty (Doktora Tezi). Ortadoğu Teknik Üniversitesi Sosyal Bilimler Enstitüsü, Ankara.

Gordon, E. W. ve Song, L. D (1994). Variations in the experience of resilience. Educational Resilience in Inner-City America: Challenges and Prospects, New Jersey: Lawrence Earlbaum Associates, Inc.

Gordon, E. W. ve Wang, M. C. (1994). Epilogue: educational resilience- challenges and prospects. Educational resilience in Inner-City America: Challenges and prospects. New Jersey: Lawrence Earlbaum Associates, Inc.

Göcen, G. (2016). Kadirşinaslık ve öznel iyi oluş: Suça sürüklenen çocuklar üzerine nicel bir araştırma. Itobiad: Journal of the Human \& Social Science Researches, 5(4).

Göka, E. ve Eroğlu, E. (2013). Hayatın anlamı var mı? İstanbul: Timaş Yayınları.

Gürgan, U. (2006). Yılmazlık ölçeği (YÖ): Ölçek geliştirme, güvenirlik ve geçerlik çalışması. Ankara Üniversitesi Ĕgitim Bilimleri Fakültesi Dergisi, 39(2), 45-74.

Harlow, L. L. ve Newcomb, M. D. (1990). Towards a general hierarchical model of meaning and satisfaction in life. Multivariate Behavioral Research, 25(3), 387-405.

Hawks, S. R. vd. (1995). Review of spiritual health: Definition, role, and intervention strategies in health promotion. American Journal of Health Promotion, 9, 371-378.

Hill, P. C., Pargament, K. I., Hood, R. W., Mccullough Jr, M. E., Swyers, J. P., Larson, D. B. ve Zinnbauer, B. J. (2013). Din ve maneviyatı kavramlaştırma: Birleşme ve ayrılma noktaları. çev. N. Kimter, Canakekale Onsekiz Mart Üniversitesi İlahiyat Fakültesi Dergisi, 3, 85-118.

Hill, H. C., Rowan, B. ve Ball, D. L. (2005). Effects of teachers' mathematical know ledge for teaching on student achievement. American Educational Research Journal, 42(2), 371-406.

Hill, P. C. ve Pargament, K. I. (2003). Advances in the conceptualization and measurement of religion and spirituality: Implications for physical and mental health research. American Psychologist, 58(1), 64-74.

Ho, M. Y., Cheung, M. F. ve Cheung, F. S. (2010). The role of meaning in life and optimism in promoting wellbeing. Personality and Individual Differences, 48, 658-663. 
Horton, T. V. ve Wallander, J. L. (2001). Hope and social support factors against psychological distress of mothers who care for children with chronic physical conditions. Rehabilitation Psychology, 46(4), 399-482.

https://www.tayfundogan.net/2016/10/20/kendini-toparlama-gucu-psikolojik-saglamlik/ (Erişim 01.08.2020)

Hu, L. T. ve Bentler, P. M. (1999). Cutoff criteria for fit indexes in covariance structure analysis: Conventional criteria versus new alternatives. Structural Equation Modeling: A Multidisciplinary Journal, 6(1), 1-55.

Ingersoll, R. E. (1994). Spirituality, religion, and counseling: dimensions and relationships. Counseling and Values, 38(2), 98-111.

İkizer, G. (2014). Factors related to psychological resilience among survivors of the earthquakes in Van, Turkey (Doktora Tezi). Ortadoğu Teknik Üniversitesi, Ankara.

Jafari, E. vd. (2010a). Spiritual well-being and mental health in university students. Procedia-Social and Behavioral Sciences, 5, 1477-1481.

Kamya, H. A. (2000). Hardiness and spiritual well-being among social work students: Implications for social work education. Journal of Social Work Education, 36(2), 231-240.

Kaner, S. ve Bayraklı, H. (2010). Aile yllmazlık ölçeği geliştirilmesi, geçerliği ve güvenirliği. Ankara Üniversitesi Eğitim Bilimleri Fakültesi Dergisi, 11(2), 47-62.

Kaner, S., Bayraklı, H. ve Güzeller, C. O. (2011). Anne-babaların yılmazlık algılarının bazı değişkenler açısından incelenmesi. Ankara Üniversitesi Eğitim Bilimleri Fakültesi Özel Eğitim Dergisi, 12(2), 063-078.

Kaplan, H. B. (1999). Toward an understanding of resilience: A critical review of definitions and models. Resilience and Development: Positive Life Adaptations, New York: Kluwer Academic/Plenum Publishers.

Kapp, L. ve Brown, O. (2011). Otizm Spektrum Bozukluğuna uyum sağlayan ailelerde dayanıklilık. Afrika'da Psikoloji Dergisi, 21(3), 459-463.

Karacoşkun, M. D. (2006). Ateist bir mistik Erich Fromm. Samsun: Etüt Yayınlar1,

Karaırmak, Ö. (2007). Deprem yaşamıs bireylerde psikolojik sağlamliğa etki eden kişisel faktörlerin incelenmesi: Bir model test etme çalışması (Doktora Tezi). Orta Doğu Teknik Üniversitesi Sosyal Bilimler Enstitüsü, Ankara.

Karasar, N. (2003). Bilimsel araștırma yöntemleri. Ankara: Nobel Yayın Dağıtım.

Kardaş, S. (2017). Sanal kimlik ve spiritüel iyi oluşun üniversite ögrencilerinin narsistik eğilimlerini yordayıcllĭg (Doktora Tezi). Marmara Üniversitesi Ë̆itim Bilimleri Enstitüsü, İstanbul

Kasapoğlu, F. (2017). Psikolojik danışma süreci ve maneviyat: Bir bütünleştirme arayışı. Hikmet Yurdu, 10(19), 141 157.

Keçeci, B. (2018). Evli kadinlarm psikolojik istismar profillerinin toplumsal cinsiyet algzlar ve spiritüel iyi oluslar açısından incelenmesi (Yüksek Lisans Tezi). Marmara Üniversitesi Eğitim Bilimleri Enstitüsü, İstanbul.

Kızılırmak, Ö. (2015). Genç yetişkinlerde yaşamda anlamın maneviyat ve kişilike özellikeleri açısından incelenmesi (Yüksek Lisans Tezi). Gazi Üniversitesi Eğitim Bilimleri Enstitüsü, Ankara.

Kitko, C. T. (2001). Dimensions of wellness and the health matters program at Penn State. Home Health Care Management \& Practice, 13(4), 308-311.

Klerk, H. ve Greeff, P. A. (2011). Resilience in parents of young adults with visual impairments. Journal of Visual Impairment \& Blindness, 414-424

Kline, R. B. (2011). Principles and practice of structural equation modeling. New York: The Guilford Press.

Klohnen, E. C. (1996). Conceptual analysis and measurement of the construct of ego resiliency. Journal of Personality \& Social Psychology, 70(5), 1067-1079.

Kobasa, S. C. (1979). Stressful life events, personality and health: an inquiry into hardiness. Journal of Personality and Social Psychology, 37(1), 1-17.

Kumpfer, K. L. (1999). Factors and processes contributing to resilience: The resilience framework. Resilience \& Development Positive Life Adaptations, New York: Kluwer Academic/Plenium Publishers.

Kurt, T. (2013). Ebeveynleri boșanmış ergenlerin yalmað̨lk, benlik saygısı, başa çıkma ve psikolojik belirtiler arasındaki ilişkinin incelenmesi: ynlmąlğgn aracı rolü (Yüksek Lisans Tezi). Gazi Üniversitesi, Ankara.

Kuşut, O. (2013). Said Nursi'de aile sosyolojisi ve sosyal ablak. Iğdır Üniversitesi, Sosyal Bilimler Enstitüsü, Iğdır.

Luthar, S. S., Cicchetti, D. ve Becker, B (2000). The construct of resilience: A critical evaluation and guidelines for future work. Child Development, 71(3), 543-562.

Luthar, S. S., Doernberger, C. H. ve Zigler, E. (1993). Resilience is not a undimensional construct. Insights from a perspective study of innercity adolescents. Development and Psychopathology, 5, 703-717.

Mahdian, Z. ve Ghaffari, M. (2016). The mediating role of psychological resilience, and social support on the relationship between spiritual wellbeing and hope in cancer patients. Journal of Fundamentals of Mental Health, 18(3), 130-138.

Marsh, V., Beard, M. T. ve Adams, B. N. (1999). Job stress and burn out: The mediation effect of spiritual well-being and hardiness among nurses. Journal of Theory Construction \& Testing, 3(1), 13-20.

Mascaro, N. ve Rosen, D. H. (2006). The role of existential meaning as a buffer against stress. Journal of Humanistic Psychology, 46, 168.

Masten, A. S. (2001). Ordinary magic: Resilience processes in development. American Psychologist, 56(3), 227-238.

Masten, A. S., Best, K. M. ve Garmezy, N. (1990). Resilience and development: Contributions from the study of children who overcome adversity. Development and Psychopathology, 2, 425-444.

Masten, A. S. ve Reed, M. G. (2002). Resilience in development. In C. R. Snyder ve S. J. Lopez (Eds.), The handbook of positive psychology (pp. 74-88). Oxford University. 
McCubbin, H. I. ve McCubbin, M. A. (1988). Typologies of resilient families: Emerging roles of social class and ethnicity. Family Relations, 37, 247-254

McCubbin, H. I., McCubbin, M. A., Thompson, A. I., Han, S. Y. ve Allen, C. T. (1997). Families under stress: What makes them resilient. Retrieved April, 2008

Newman, R. (2005). APA's resilience initiative. Professional Psychology: Research and Practice, 36(3), 227-229.

Opatz, J. P. (1986). Stevens point: A longstanding program for students at a Midwestern University. American Journal of Health Promotion, 1(1), 60-67.

Öğülmüş, S. (2001). Bir kişilik özelliği olarak yilmazlık. I. Ulusal çocuk ve suç semposyumu, nedenler ve önleme çalıs̆malar, 2930 Mart, Ankara.

Özbay, Y. ve Aydoğan, D. (2014). Aile yılmazlığı: bir engele rağmen birlikte güçlenen aile. Sosyal Politikalar Calışmalar Dergisi, 14(31), 129-146.

Özcan B. (2005). Anne-babalar bosanmıs ve anne-babalar birlikte olan lise ögrencilerinin yalmaz̨hk özellikleri ve koruyucu faktörler açısından karşılaştırlması (Yüksek Lisans Tezi). Ankara Üniversitesi Eğitim Bilimleri Enstitüsü, Ankara.

Parlak, S. (2014). Yükesek Ögrrenim Kredi Yurtlar Kurumunda barnan kerz ögrencilerin yaşam anlam düzeyleri ile psikolojik dayanılillklar arasindaki ilişki (İstanbul örneği). İstanbul: Marmara Üniversitesi.

Pattakos, A. (2010). Prisoners of our thoughts. California: Berrett-Koehler Publishers.

Patterson, J. (2002). Integrating family resilience and family stress theory. Journal of Marriage and Family, 64, 349-360.

Rhodes, W. A. ve Brown, W. K. (1991a). Introduction and review of the literature. why some children succeed despite the odds. New York: Praeger Publishers.

Runzo, J. ve Martin, N. M. (2002). Dünya dinlerinde hayatın anlamı (Çev: G. Varım). İstanbul: Say Yayınları.

Rutter, M. (1987). Psychosocial resilience and protective mechanisms. American Journal of Orthopsychiatry, 57, $316-331$.

Ryff, C. D. (1989). Happiness is everything, or is it? Explorations on the meaning of psychological well-being. Journal of Personality and Social Psychology, 57(6), 1069-1081.

Seligman, M. E. P. (2007). Gerçek mutluluk (Çev: S. Kunt Akbaş). Ankara: HYB Basım Yayın

Seligman, M. ve Csikzentmihalyi, M. (2000). Positivepsychology: An introduction. American Psychologist, 55, 5-14.

Sims, K. M. E. (2000). Hardiness and spiritual well-being as moderators of burnout in professional nurses. Dissertation Abstracts International, 61(3-B), 1330.

Söylemez, A. (2016). Manevi zekânın yaşamın anlamı ve yașam doyumunun yordayııısı olarak incelenmesi (Yüksek Lisans Tezi). Sakarya Üniversitesi, Eğitim Bilimleri Enstitüsü, Sakarya.

Steger, M. F., Kashdan, T. B., Sullivan, B. A. ve Lorentz, D. (2008). Understanding the search for meaning in life: personality, cognitive style and the dynamic between seeking and experiencing meaning. Journal of Personality, $76(2), 199-228$.

Steger, M. F., Oishi, S. ve Kesebir, S. (2011). Is a life without meaning satisfying? The moderating role of the search for meaning in satisfaction with life judgments. The Journal of Positive Psychology, 6(3), 173-180.

Steger, M. ve Frazier M. (2005). Meaning in life: one link in the chain from religiousness to well-being. Journal of Counseling Psychology, 52(4), 574-782.

Süataç, A. (2010). Evlilik uyumunun kişilerarası tarž ve öfke açısından araştırlması (Yüksek Lisans Tezi). Ege Üniversitesi, İzmir.

Şahin, M., Aydın, B., Sarı, S. V., Kaya, S. ve Pala, H. (2012). Öznel iyi oluşu açıklamada umut ve yaşamda anlamın rolü. Kastamonu Ë̆itim Dergisi, 20(3), 827-836.

Şimşir, Z., Boynueğri, S. ve Dilmaç, B. (2017). Religion and spirituality in the life of individuals with paraplegia: Spiritual journey from trauma to spiritual development. Spiritual Psychology and Counseling, 2, 89-110.

Şimşir, Z., Seki, T. ve Dilmaç, B. (2018). Predictive relationships between adolescents' spiritual well being and perceived social support: The role of values. Research on Education and Psychology, 2(1), 37-46.

Şirin, T. (2018). Maneviyat Ölçeği'nin Geliştirilmesi: Geçerlik ve Güvenirlik çalışması. Turkish Studies, 13(18) 12831309.

Şirin, T. (2019). Evli çiftlerin spiritüel iyi oluşları ile evlilik doyumları arasındaki ilişki. Ekev Akademi Dergisi. 23(77), 389-410.

Tanaka, J. S. ve Huba, G. J. (1985). A fit index for covariance structure models under arbitrary GLS estimation. British Journal of Mathematical and Statistical Psychology, 38(2), 197-201.

Tarhan, N. (2014). Mutlu evlilik psikolojisi. İstanbul. Timaş Yayınları.

Tedeschi, R. G. ve Calhoun, L. G. (2004). Posttraumatic growth: Conceptual foundations and empirical evidence. Psychological inquiry, 15(1), 1-18.

Telatar, T. G. ve Özcebe, H. (2004). Yaşlı nüfus ve yaşam kalitelerinin yükseltilmesi. Türk Geriatri Dergisi, 7(3),162165.

Terzi, Ş. (2005). Öznel iyi olmaya ilişkin psikolojik dayanılllık modeli (Doktora Tezi). Gazi Üniversitesi Eğitim Bilimleri Enstitüsü, Ankara.

Terzi, Ş. (2008). Üniversite öğrencilerinin psikolojik dayanıklılıkları ve algıladıkları sosyal destek arasındaki ilişki. Türk Psikolojik Danisma ve Rebberlik Dergisi, 29, 1-9.

Tillich, P. (2014). Olmak cesareti (Çev. F. C. Dansuk) İstanbul: Okuyan Us Yayınları.

Turanlı, P. (2010). Orta yetişkinlikte evlilik uyumu ile benlik saygısı ve bağlanma stilleri arasındaki ilişkinin saptanması (Yüksek Lisans Tezi). Maltepe Üniversitesi Sosyal Bilimler Enstitüsü, İstanbul. 
Türksoy, N. (2003). Psikolojik travma ve tanım sorunları. Psikolojik Travma ve Sonuclar, Editör: T. Aker, M. E. Önder, 5US Yayınc1lik, 9-21.

Uğurluoğlu, D. ve Erdem, R. (2019). Travma geçiren bireylerin spiritüel iyi oluşlarının travma sonrası büyümeleri üzerine etkisi. Dokuz Eylul University Journal Of Graduate School of Social Sciences, 21(3).

Walsh, F. (2002). A family resilience framework: 1nnovative practice applications. Family Relations, 51(2), 1-14.

Wang, M. C., Haertel, G. D. ve Walberg, H. J. (1994). Educational resilience in inner cities. Educational Resilience in Inner-City America: Challenges and Prospects, New Jersey: Lawrence Earlbaum Associates, Inc.

Werner, E. E. (1989). High-risk children in young adulthood: A longitudinal study from birth to 32 years. American Journal of Orthopsychiatry. 59, 72-81.

Westgate, C. E. (1996). Spiritual wellness and depression. Journal of Counseling \& Development, 75(1), 26-35.

Windle, M. (1999). Critical conceptual and measurement issues in the study of resilience. Resilience and Development: Positive Life Adaptations, New York: Kluwer Academic/Plenum Publishers.

Yıkılmaz, M. ve Demir-Güdül, M. (2015). Üniversite öğrencilerinde yaşamda anlam, bilinçli farkındalık, algıllanan sosyoekonomik düzey ve yaşam doyumu arasındaki ilişkiler. Ege Eğitim Dergisi, 16(2), 297-315.

Zengin, B. (2013). Özel eğitime mubtaç çocuğa sahip ebeveynlerin algiladıklar sosyal destek, psikolojik dayanılillk ve umut düzeyleri (Yüksek Lisans Tezi). Gazi Üniversitesi Eğitim Bilimleri Enstitüsü, Ankara.

\section{EXTENDED ABSTRACT}

The family institution is very important for both society and individuals. The family is a universal institution that no social group or institution can replace (Kuşut, 2013). This institution, which offers individuals the first opportunity to socialize, is also the shaper and building block of society. A happy, prosperous and strong society is a society consisting of families composed of healthy individuals. This healthy structure can be provided by the marriage institution. The marriage institution is one of the most important institutions that keep societies alive (Süataç, 2010). Marriage is an institution formed by two strangers with differences in family styles and thinking systems with their own new behaviors and new thinking systems (Turanl, 2010).

With marriage, individuals have the opportunity to meet their various needs, to continue their generation, and to live a more organized life. Thus, it becomes easier for individuals to fulfill their social functions and adapt to society. A healthy marriage acts as a shelter for happiness. One can get rid of all the difficulties of the day at home and experience the sharing of emotions. In addition, for a healthy married individual, home is the place where he feels safe and belonging. It has been determined that people who feel trust in their marriage are happier and have a longer life span (Tarhan, 2014).

According to Frankl (2009, p. 113), the meaning of life is closely related to one's possession of the purposes that make his life worthwhile and is a motivating factor which is the basis for the life for sustaining, varying from person to person. The special structure of the meaning requires that only the individual himself could find the meaning. The most effective factor in the survival of a person even in the worst conditions is the knowledge that there is meaning in his life. Meaninglessness occurs when individuals think of themselves as undirected, aimless, insoluble, inadequate (Harlow, \& Newcomb, 1990, p. 387-405) and conditions such as distress, depression, suicidal ideation may be observed in the absence of meaning (Akı1n, \& Taş, 2011, p. 30; Arda, 2011, p. 9).

Resilience is defined by Walsh (2006, p.261-281) as an active process that enables one to come out of the situation stronger when faced with a challenge, to improve in a crisis, and to be resistant. Resilience covers a process rather than a personality trait (Luthar, Cicchetti, \& Becker, 2000, p. 543-562). Like personality development consists of a combination of genetic and environmental factors, although there are some genetic facilitating factors for resilience, it can be stated that it is a trait that can be improved later on. One can learn to show resilient behaviors (Ekşi, Boyal, \& Ümmet, 2018, p. 1698).

The concept of morale/spirituality is often confused with the concept of religion, but it does not have the same meaning. While spirituality adds meaning to the practices of the religion, the religion deepens spirituality (Adams et al., 2000, p. 166; Ingersoll, 1994, p. 105). Although spirituality is a component of religion, it is far too comprehensive to be limited only to religious belief. Spirituality is not a situation covering just religious people, people who do not have religious beliefs can also have spiritual values (Kizilirmak, 2015, p. 41). It is stated that spirituality, whose importance has increased with the addition of spiritual and religious problems to the DSM-IV and with the increasing interest in psychospiritual practices, is also very important for a healthy mood and spiritual development (Kasapoğlu, 2017, p. 152). 
Based on all these, we can say that individuals with high spiritual well-being are at a better point in terms such as making sense of life, looking at the future with hope, sharing, being strong against difficulties, self-reliance, and being satisfied with their life. This situation increases the psychological and mental well-being of individuals and can reduce the possibility of going into depression. Individuals with high spiritual well-being can suffer less from traumatic experiences by believing in the existence of superior power and thinking "there is a no in this too". (Uğurluoğlu, \& Erdem, 2019)

It shapes a person's behaviors, value judgments, attitudes towards events, and perspective on life in which he displays a spiritual identity, which tells us that spirituality is a transcendent state that is relevant to all aspects of an individual's life (Baldwin, 2003; Westgate, 1996). Kitko (2001, p. 310) also stated in his study that spirituality depends on individuals' value judgments, moral attitudes, attitudes towards other people, and the environment. In other words, the spiritual well-being of the individuals and their personality traits are in interaction. This situation may have an impact on the change and transformation that individuals will experience as a result of traumatic events (Uğurluoğlu \& Erdem, 2019).

Findings indicated that $\mathrm{It}$ is seen that the most important independent variable affecting resilience in the family of married individuals is spiritual well-being. Secondly, It has been determined that the most important variable affecting the meaning of life variable in married individuals) is spiritual well-being. Finally, It has been observed that the most important variable affecting the resilience variable in married individuals is the variable of the meaning of life. 